Gut, 1981, 22, 70-76

Case report

\title{
Granular cell myoblastoma of the common bile duct treated by biliary drainage and surgery
}

\author{
J DEWAR,* J S DOOLEY, † I LINDSAY, P GEORGE, AND S SHERLOCK \\ From the Departments of Medicine, Surgery, and Pathology, Royal Free Hospital, London
}

SUMMARY A young Caucasian woman is described in whom obstructive jaundice was caused by a granular cell myoblastoma of the common bile duct. She was treated by percutaneous transhepatic biliary drainage for 10 days, before radical removal. Granular cell myoblastomas are benign lesions of disputed histogenesis, rare among biliary neoplasms, the excision of which is curative.

Benign tumours of the extrahepatic biliary tree are rare, and are usually either epithelial (adenomas and papillomas) or have a prominent epithelial component (adenomyomas and polyps). ${ }^{12}$ Fibromas, leiomyomas, nerve sheath tumours, and granular cell myoblastomas account for $13 \%{ }^{3}$ Since the first report of a biliary myoblastoma, ${ }^{4}$ others have been described, usually in negro females (Tables 1 and 2). The only previous case in the British literature was, as in this report, in a young Caucasian woman who presented with obstructive jaundice. $^{5}$

\section{Case report}

A 28 year old single Greek woman presented in March 1979 to the Royal Free Hospital, for investigation of jaundice, which was first noted in March 1977. She had previously been well, and had taken an oestrogen/progesterone oral contraceptive since 1970. Between March 1977 and September 1978 she had a variable degree of cholestasis with dark urine and pale stools, and there had been no improvement with a short course of steroids. In September 1978 itching developed and a liver biopsy was reported as consistent with chronic cholestasis.

On examination she was a tall fit young woman, jaundiced with increased pigmentation of exposed areas and skin folds, and scratch marks on her limbs.

*Present address: Department of Medicine, Vancouver General Hospital, Vancouver BC, Canada.

†Address for correspondence and reprint requests: Dr J S Dooley, Royal Free Hospital, Pond Street, London NW3. JSD is a Saltwell Research Fellow of the Royal College of Physicians of London.

Received for publication 9 August 1980
There was $10 \mathrm{~cm}$ smooth, non-tender hepatomegaly. The tip of the spleen was palpable.

Investigations showed: haemoglobin $10.0 \mathrm{~g} / \mathrm{dl}$, white cell count $13 \times 10^{9} / 1$ with a normal differential count. Total bilirubin $220 \mu \mathrm{mol} / \mathrm{l}$, aspartate transaminase $51 \mathrm{IU} / 1$, and alkaline phosphatase 413 IU/l. Serum albumin, gamma globulin, and immunoglobulins were normal. Serum autoantibodies and hepatitis B surface antigens were negative.

Ultrasound of the liver (Fig. 1) showed marked dilatation of the intrahepatic bile ducts and the common hepatic duct. Percutaneous transhepatic cholangiography (PTC) showed complete obstruction of the common hepatic duct (Fig. 2). Endoscopic retrograde cholangiopancreatography (ERCP) showed a normal common bile duct up to the level of the origin of the cystic duct, where there was a tight stricture (Fig. 3). Some contrast medium passed through the stricture and showed the dilated biliary system above the lesion. The pancreatic duct was normal.

A percutaneous drainage catheter (PTD) was introduced through the liver into the dilated biliary system (Fig. 2). External drainage was done for 10 days and the daily output of bile was between 2 and 5 litres. Sodium and water balance was maintained by intravenous infusion, and there were no complications from the procedure. Over the period of drainage, the serum bilirubin concentration fell from 192 to $78 \mu \mathrm{mol} / 1$ (Fig. 4) and elective surgery was then performed.

At operation there was an apparently intraluminal tumour in the common bile duct with proximal dilatation of the duct. The common bile 
Table 1 Granular cell myoblastoma of extrahepatic biliary system: common bile duct

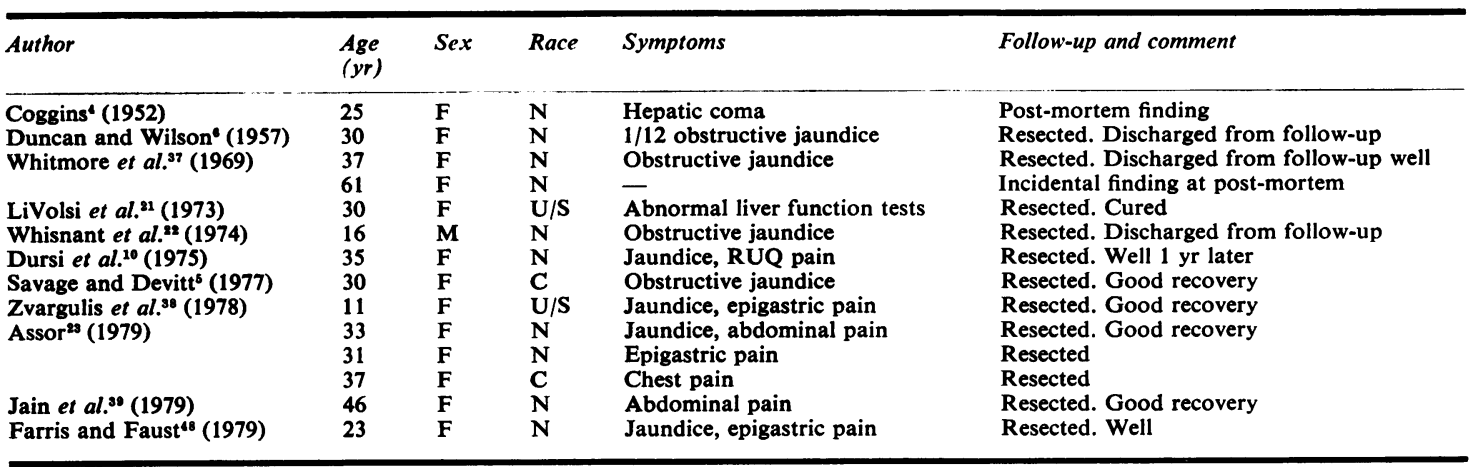

N: Negroid. C: Caucasoid. M:Mongoloid. U/S: Unspecified, RUQ: right upper quadrant.

duct was divided below the tumour. The gall bladder, cystic duct, and tumour, with a rim of common hepatic duct, were removed, together with local lymphatics and nodes. A hepaticojejunostomy and enteroanastomosis were constructed.

Her postoperative course was uncomplicated and she was discharged 10 days later. She remains well and free from jaundice 10 months later.

\section{PATHOLOGICAL FINDINGS}

The resected specimen (Fig. 5) was of gall bladder and cystic duct with $1.0 \mathrm{~cm}$ of dilated common bile duct. A firm solitary mass $1.2 \mathrm{~cm}$ in axial length with a yellow cut surface obliterated the lumen of the common bile duct without involvement of the serosa.

Histologically the tumour consisted of large eosinophilic cells in strands or solid clumps with uniform small dark nuclei and distinct margins (Fig. 6). The cytoplasm contained granules, closely packed and varying in size, which were strongly positive with the periodic acid-Schiff reaction after amylase digestion. Faint Sudan Black positivity was found on frozen section. No cross-striations or fibrillary processes were seen. The stroma between tumour cells was collagenous and occasionally myxoid. The edges of the lesion were ill-defined, the granular cells singly or in groups infiltrating, but not destroying, muscle. Occasionally, cells were arranged in whorls around small nerve bundles (Fig. 7), a finding frequently noted in relation to biliary myoblastomas. ${ }^{56}$

The ultrastructural findings (Fig. 8) were of membrane-bound vesicles of various sizes with moderate to dense osmiphilia, together with many myelin figures and much electron dense material in mitochondria and Golgi apparatus. These appearances are characteristic of myoblastomas. ${ }^{78}$ No axons were found within tumour cells, nor evidence of transition from tumour cells to small nerves or myofibils.

Immunoperoxidase studies on paraffin-embedded tissue sections did not demonstrate carcinoembryo-

Table 2 Granular cell myoblastoma of extrahepatic biliary system: cystic duct and gall bladder

\begin{tabular}{|c|c|c|c|c|c|}
\hline Author & $\begin{array}{l}\text { Age } \\
(y r)\end{array}$ & Sex & Race & Symptoms & Follow-up and comment \\
\hline $\begin{array}{l}\text { Cystic duct } \\
\text { Fialho and Hilario }{ }^{40}(1952) \\
\text { Serpe et al. } .^{41}(1960) \\
\text { Goldman et al. }{ }^{42}(1967) \\
\text { Mackay et al. } .^{43}(1968) \\
\text { Christensen and Ishak }{ }^{44}(1970) \\
\text { Abt et al. }{ }^{45}(1971) \\
\text { LiVolsi et al. } .^{21}(1973)\end{array}$ & $\begin{array}{l}21 \\
34 \\
14 \\
34 \\
34 \\
44 \\
40\end{array}$ & $\begin{array}{l}\mathbf{F} \\
\mathbf{F} \\
\mathbf{F} \\
\mathbf{F} \\
\mathbf{F} \\
\mathbf{F}\end{array}$ & $\begin{array}{l}\mathbf{N} \\
\mathbf{N} \\
\mathbf{N} \\
\mathbf{U} / \mathbf{S} \\
\mathbf{C} \\
\mathbf{N} \\
\mathbf{U} / \mathbf{S}\end{array}$ & $\begin{array}{l}\text { RUQ pain } \\
\text { RUQ pain } \\
\text { RUQ pain } \\
\text { RUQ pain } \\
\text { RUQ pain } \\
\text { RUQ pain } \\
\text { RUQ pain }\end{array}$ & $\begin{array}{l}\text { Resected. Well } \\
\text { Resected. Well } \\
\text { Resected. Well } \\
\text { Resected. Well at } 9 \mathrm{~m} \\
\text { U/S } \\
\text { Resected } \\
\text { Died of myocardial infarction at } 4 \mathrm{yr} \text {. } \\
\text { Post-mortem no recurrence or spread }\end{array}$ \\
\hline $\begin{array}{l}\text { Kittredge and Baer }{ }^{49}(1975) \\
\text { Farris and Faust }{ }^{48}(1979) \\
\text { Reul et } \text { al. }^{46}(1975)\end{array}$ & $\begin{array}{l}41 \\
31 \\
39\end{array}$ & $\begin{array}{l}\mathbf{F} \\
\mathbf{F} \\
\mathbf{F}\end{array}$ & $\begin{array}{l}\mathbf{U} / \mathbf{S} \\
\mathbf{N} \\
\mathbf{N}\end{array}$ & $\begin{array}{l}\text { Jaundice and pain } \\
\text { Epigastric pain } \\
\text { RUQ pain }\end{array}$ & $\begin{array}{l}\text { Conservative procedure } \\
\text { Resected. Well } \\
\text { Resected }\end{array}$ \\
\hline $\begin{array}{l}\text { Gall bladder } \\
\text { Ishii et al. }{ }^{47} \text { (1977) }\end{array}$ & 39 & $\mathbf{F}$ & $\mathbf{M}$ & Epigastric pain & \\
\hline
\end{tabular}

Abbreviations as in Table 1. 
Fig. 1 Gray scale ultrasound of liver showing dilated intrahepatic ducts (arrowed).

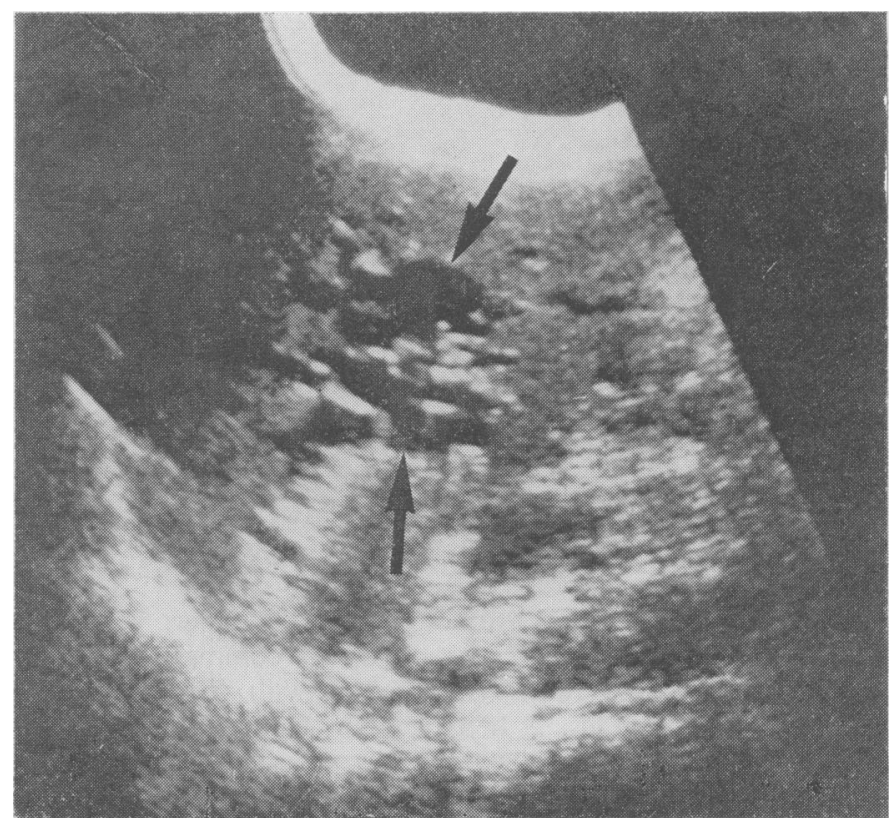

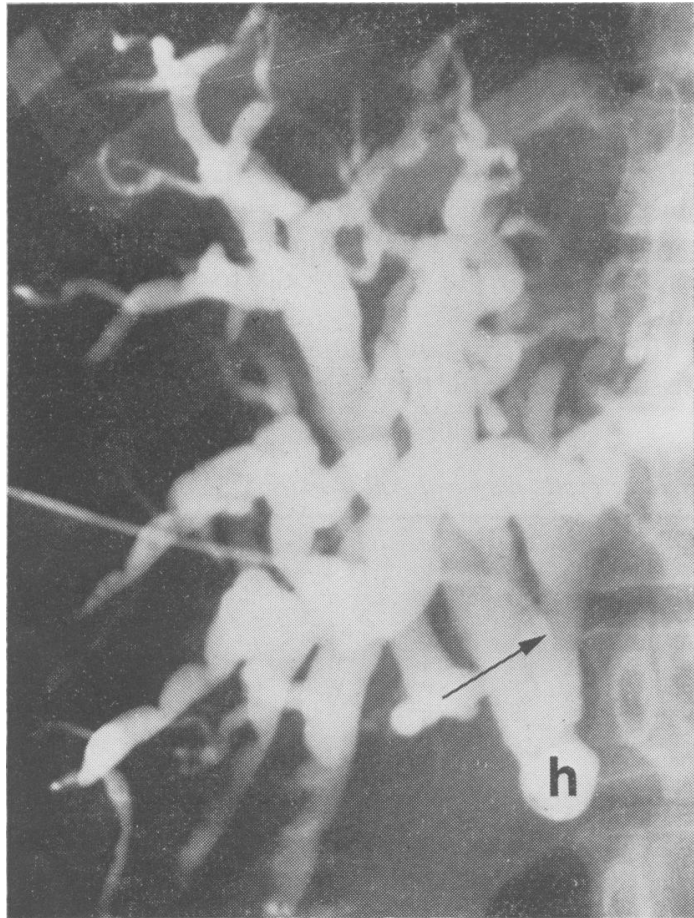

Fig. 2 PTC with dilated intrahepatic ducts, obstruction of the common hepatic duct $(h)$, and the drainage catheter in the biliary system (arrowed). mic antigen (CEA). Myoblastomas occurring in breast have been found to be CEA positive. ${ }^{9}$

\section{Discussion}

Benign tumours of the extrahepatic bile ducts are rare $^{3}$ and less than $10 \%$ are granular cell myoblastomas (GCM). ${ }^{10}$ Review of the literature has shown 25 previous reports of GCMs involving the biliary tract (Tables 1 and 2). The clinical features on presentation depended on the anatomical site of the tumour. Common bile duct tumours presented with jaundice and those in, or at the origin of, the cystic duct with abdominal pain. These clinical features and the preoperative investigations were of no specific value in the diagnosis, this being made in almost every case on histological examination. Resection was curative, but the biliary surgery was often followed by complications including stricture, requiring additional operations.

Our patient presented with an unusual history of two years of cholestasis. The history was non-specific, though the occurrence of jaundice before itching was more consistent with extrahepatic obstruction rather than intrahepatic cholestasis, as, for example, primary biliary cirrhosis, when itching usually occurs before jaundice. ${ }^{11}$

Ultrasound examination demonstrated bile duct dilatation, and PTC and ERCP showed the site of 


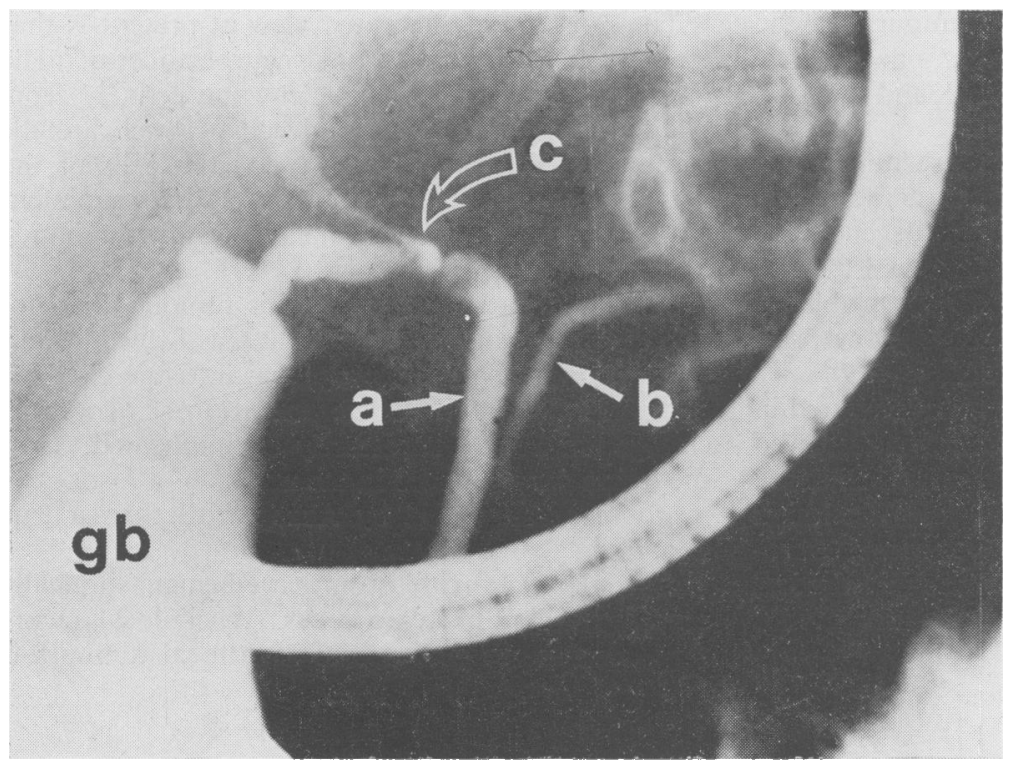

Fig. 3 ERCP showing normal common bile duct $(a)$, and pancreatic duct (b), with dilation of the common hepatic duct above a stricture (c) at the origin of the cystic duct. Gall bladder ( $g b$ ).

obstruction. The cholangiographic appearances were consistent with cholangiocarcinoma, but at surgery the lesion was thought to be benign. Histological examination confirmed this.

Several techniques can now be used to drain obstructed bile ducts before or in place of surgery. ${ }^{12}$ Preoperative external bile drainage was done in this case. Nakayama et al. ${ }^{13}$ have claimed a reduc-

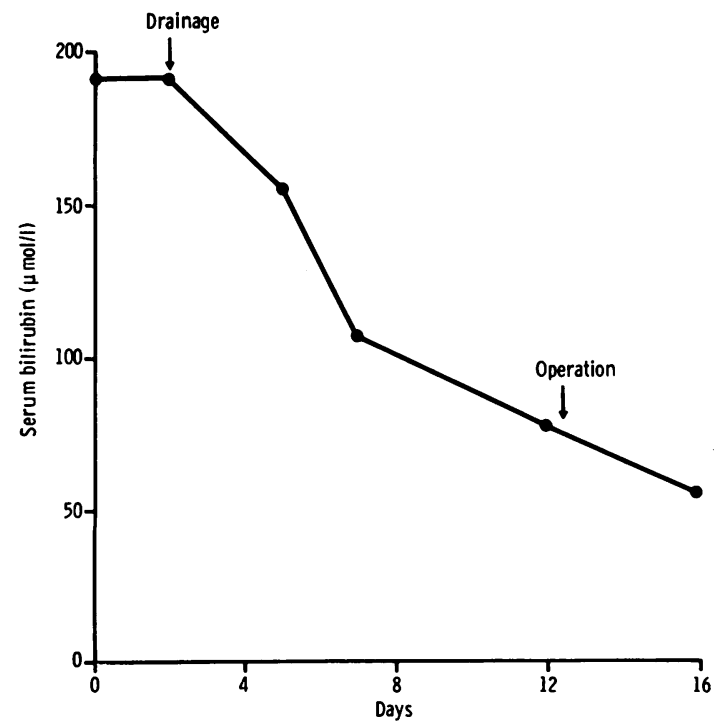

Fig. 4 Fall in serum bilirubin concentration during preoperative external biliary drainage. tion in postoperative mortality using this technique in patients with obstructive jaundice, and for this reason, and also to decompress an unusually tense biliary system after PTC, external drainage was done. The flow of bile was five times that expected and remains unexplained. Internal bile drainage, although preferable, was not possible.

Strict fluid balance, necessary in all cases with bile drainage, was critical, with parenteral replacement of salt and water. Serum bilirubin fell as expected, but whether such a reduction before surgery reduces the operative risk is not established.

Granular cell myoblastomas arise more frequently in the oral cavity, in skin and subcutaneous tissues, than in the biliary tract. They have also been described in other sites including breast, ${ }^{14}{ }^{15}$ female genital tract, ${ }^{16}$ bronchus, ${ }^{17} 18$ and in the gastrointestinal tract. So far as is known, this patient had

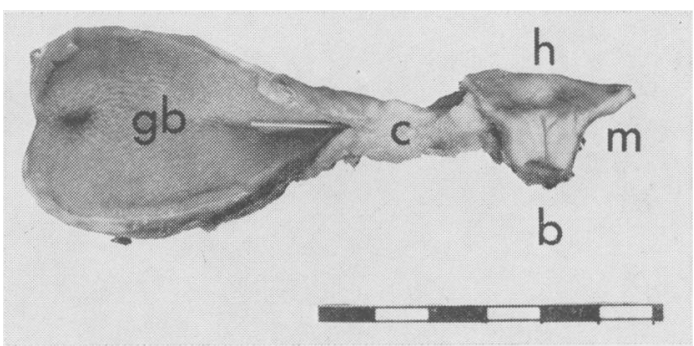

Fig. 5 Resected specimen showing tumour $(m)$ at the origin of the cystic duct (c), with common hepatic duct ( $h$ ) above, and common bile duct (b) below. Gall bladder $(\mathrm{gb})$. 
only one myoblastoma, but these tumours can be multiple ${ }^{19}{ }^{20}$ and, of the 22 biliary cases, one patient ${ }^{21}$ had multiple tumours in the biliary tree, and four had myoblastomas elsewhere. ${ }^{21-23}$

The nature and histogenesis of these tumours is uncertain. It has been argued that the lesion is neoplastic, ${ }^{24}$ a storage disorder, ${ }^{25}$ and a degenerative change. ${ }^{8}$ The cell of origin is also unknown. Embryonic muscle, Schwann cells, perineural fibroblasts, phagocytic histiocytes, and modified astrocytes in the pituitary ${ }^{26}$ have all been suggested.

Embryonic striated muscle cells were suggested in the original description, ${ }^{27}$ and this has received support. ${ }^{28}{ }^{29}$ The characteristics of the cells in tissue culture also suggest a myogenic origin. ${ }^{30}$ The lesion has been called a granular cell perineural fibroblastoma $^{31}$ and a lipid thesaurismosis, ${ }^{25}$ a local metabolic disorder in which histiocytes store lipoid material and appear granular.

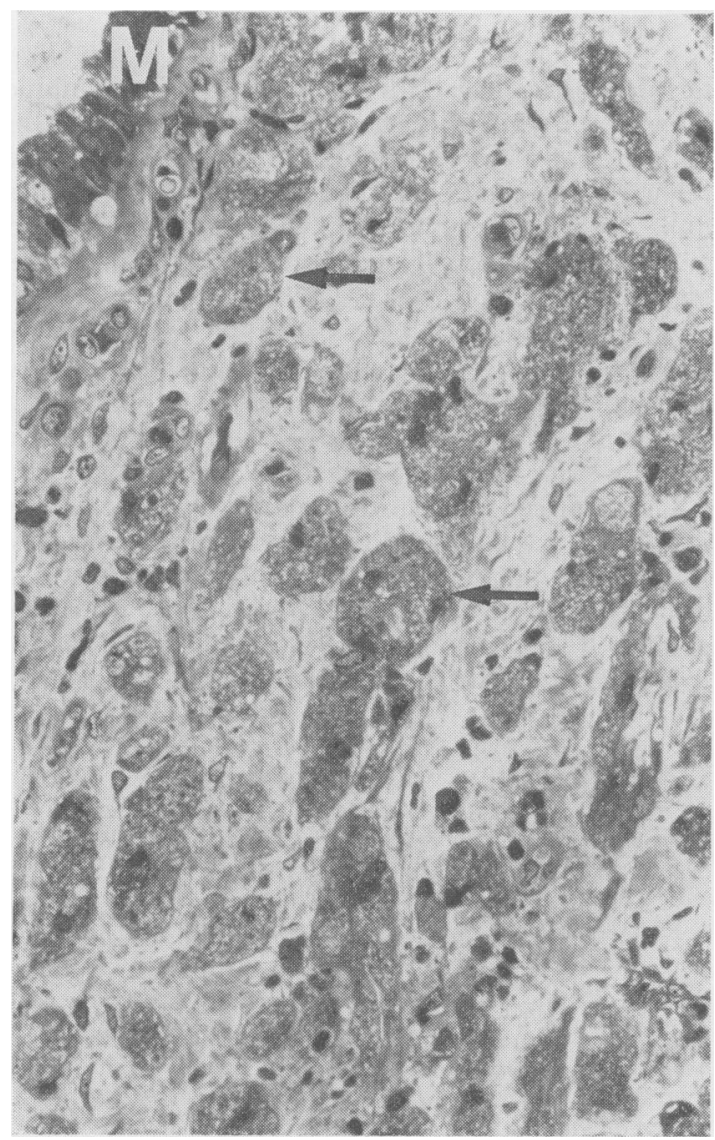

Fig. 6 Submucosal area showing tumour cells (two arrowed). Mucosa of bile duct (M).
The most widely accepted view at present is that these tumours arise from neuroectoderm. The lesions could develop from Schwann cells, ${ }^{32} 8$ from undifferentiated mesenchymal cells ${ }^{33}$ which are the precursors of Schwann cells, ${ }^{7}$ or from cells of the nerve sheath, like neurofibromas. ${ }^{34}$ In this patient granular cells were seen within and closely surrounding nerve bundles (Fig. 7).

The proliferative nature of this tumour does not rule out a Schwann cell origin, but, as Schwann cells may assume phagocytic properties in tissue culture ${ }^{35}$ and possibly in Wallerian degeneration, ${ }^{8}$ a neoplastic change would not necessarily be implicated. Thus the lesion may be more in the nature of a histiocytic response as suggested by Azzopardi ${ }^{25}$ than a true neoplasm. ${ }^{36}$

Granular cell myoblastomas are benign, surgically curable, and unlikely to recur. When local recurrence occurs the presence of multifocal tumours is

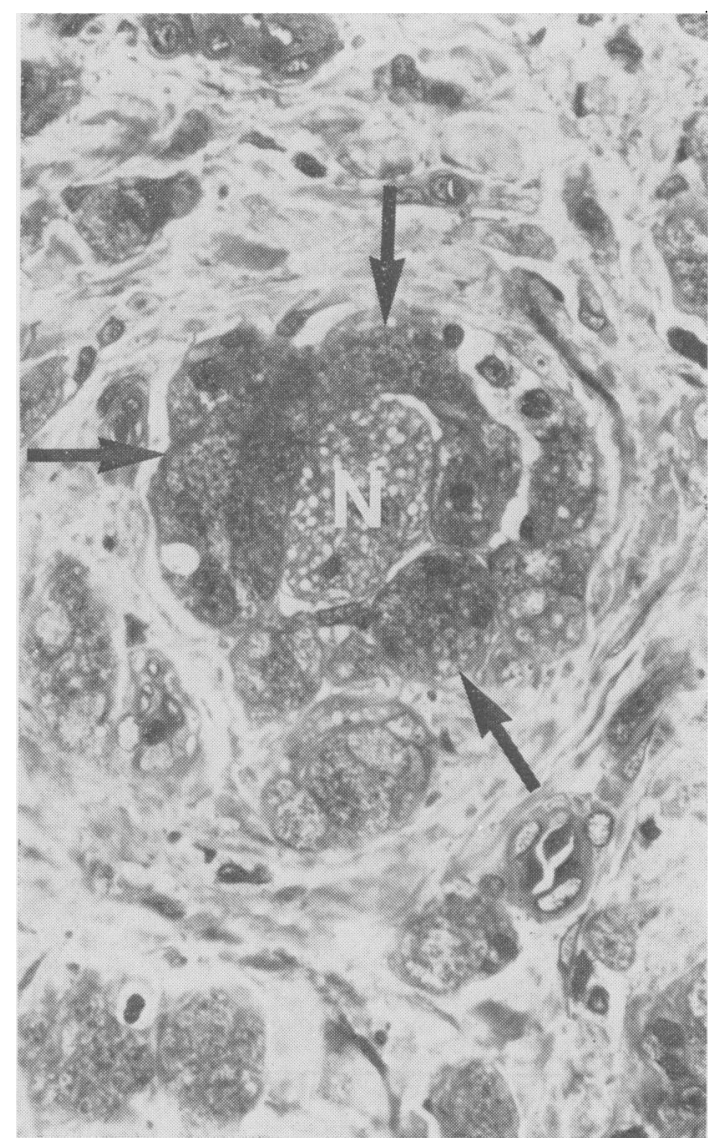

Fig. 7 Tumour cells (arrowed) in whorls around small nerve trunk $(N)$. 


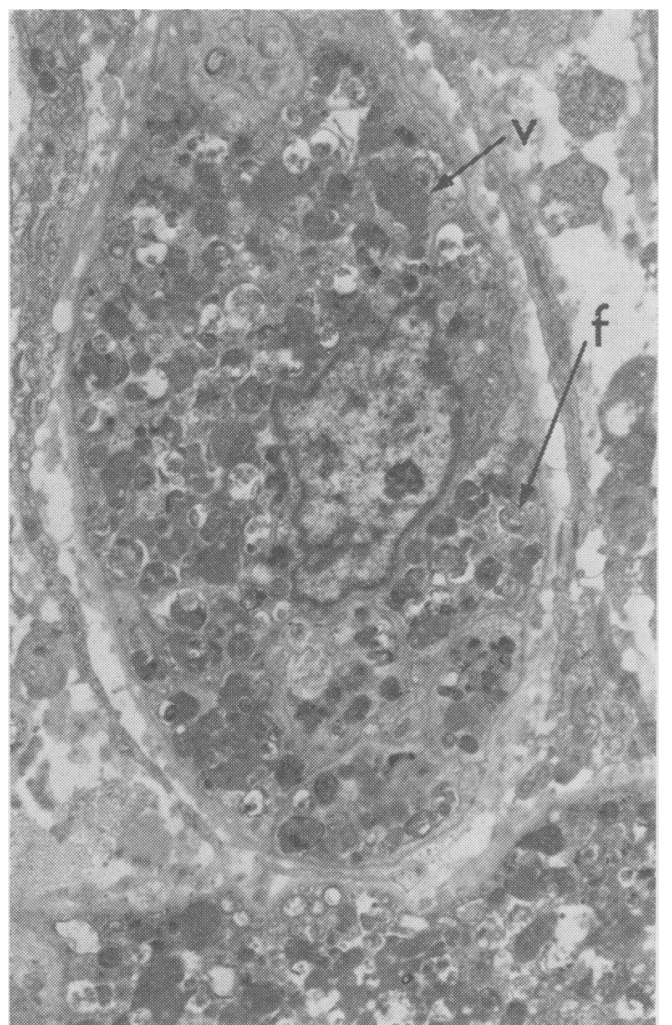

Fig. 8 Electron micrograph showing membrane bound vesicles $(v)$ and myelin figures $(f)$.

likely. If aggressive local invasion or metastasis occurs, large cell sarcomas such as rhabdomyosarcomas must be considered. Cadotte ${ }^{24}$ accepts a total of 22 malignant granular myoblastomas in the literature, none in the biliary tree, mainly arising subcutaneously and spread by lymphatics or the blood system.

We report this patient as a rare case with bile duct obstruction due to a benign tumour. Granular cell myoblastomas are probably of Schwann cell origin. Our patient is well at follow-up 10 months after radical surgery.

The authors wish to thank Dr R Dick and Dr J A Summerfield for the cholangiograms, Miss $\mathbf{J}$ Lewin and $\mathrm{Mr} \mathrm{P}$ Bates for the photomicrographs, and Dr J Hinton for the ultrasonogram.

\section{References}

${ }^{1}$ Dowdy GS, Olin WG, Shelton EL, Waldron GW. Benign tumours of the extrahepatic bile ducts. Arch Surg 1962; 85: 503-13.
${ }^{2}$ Hossack KF, Heron JJ. Benign tumours of the common bile duct. Aust NZ J Surg 1972; 42: 22-6.

${ }^{3} \mathrm{Chu}$ PT. Benign neoplasms of the extrahepatic biliary ducts. Arch Pathol Lab Med 1950; 50 : 84-97.

${ }^{4}$ Coggins RP. Granular cell myoblastoma of the common bile duct; a report of a case with autopsy findings. Arch Pathol Lab Med 1952; 54: 398-402.

${ }^{5}$ Savage A, Devitt P. Granular cell myoblastoma of the biliary tree. Postgrad Med J 1977; 53: 574-7.

${ }^{6}$ Duncan JT, Wilson H. Benign tumours of the common bile duct. Ann Surg 1957; 145: 271-4.

${ }^{7}$ Sobel HJ, Schwarz R, Marquet E. Light and electron microscope study of the origin of granular-cell myoblastoma. J Pathol 1973; 109: 101-11.

${ }^{8}$ Fisher ER, Wechsler H. Granular cell myoblastoma-a misnomer. Cancer 1962; 15: 936-54.

${ }^{9}$ Shousha S, Lyssiotis T. Correlation of carcinoembryonic antigen in tissue sections with spread of mammary carcinoma. Histopathology 1978; 2: 433-47.

${ }^{10}$ Dursi JF, Hirschl S, Gomez R, Mersheimer WL. Granular cell myoblastoma of common bile duct; report of a case and review of the literature. Rev Surg 1975; 32: 305-10.

${ }^{11}$ Sherlock S, Scheuer PJ. The presentation and diagnosis of 100 patients with primary biliary cirrhosis. $N$ Engl J Med 1973; 289: 674-8.

${ }^{12}$ Dooley JS, Dick R, Olney J, Sherlock S. Non-surgical treatment of biliary obstruction. Lancet 1979; 2 : 1040 44.

${ }^{13}$ Nakayama T, Ikeda A, and Okuda K. Percutaneous transhepatic drainage of the biliary tract. Gastroenterology 1978; 74: 554-9.

${ }^{14}$ Mulcare R. Granular cell myoblastoma of the breast. Ann Surg 1968; 168: 262-8.

${ }^{15}$ Vidyarthi SC. Granular cell myoblastoma of the breast. Arch Surg 1969; 98: 662-7.

${ }^{16}$ Hertig AT, Gore H. Tumors of the female sex organs. Atlas of tumor pathology Washington, DC: Armed Forces Institute of Pathology, 1960: part 2.

${ }^{17}$ Campbell DC, Smith EP, Hood RH. Benign granular cell myoblastoma of the bronchus. Review of the literature and report of a case. Chest 1964; 46: 729-33.

${ }^{18}$ Roje CI. Multiple endobronchial myoblastomas. Arch Otolaryngol 1965; 82: 652-5.

${ }^{19}$ Moscovic EA, Azar HS. Multiple granular cell tumours (myoblastomas). Cancer 1967; 20: 2032-47.

${ }^{20}$ Vance SF, Hudson RP. Granular cell myoblastoma. Clinicopathologic study of 42 patients. Am J Clin Pathol 1969; 52: 208-11.

${ }^{21}$ LiVolsi VA, Perzin KH and Badder EM. Granular cell tumours of the biliary tract. Arch Pathol Lab Med 1973; 95: 13-7.

${ }^{22}$ Whisnant JD, Bennett SE, Huffman SR, Weiss DL, Parker JC, Griffin WO. Common bile duct obstruction by granular cell tumour (Schwannoma). Dig Dis Sci 1974; 19: 471-6.

${ }^{23}$ Assor D. Granular cell myoblastoma involving the common bile duct. Am J Surg 1979; 137 : 673-5.

${ }^{24}$ Cadotte M. Malignant granular cell myoblastoma. Cancer 1974; 33: 1417-22.

${ }^{25}$ Azzopardi JG. Histogenesis of the granular cell myoblastoma. J Pathol 1956; 71 : 85-94. 
${ }^{26}$ Burston J, John R, Spencer H. Myoblastoma of the neurohypophysis. J Pathol 1962; 83: 455-61.

${ }^{27}$ Abrikossoff Al. Über myome, ausgehend von der quergestreiften willkürlichen muskulatur. Virchows Arch (Pathol Anat) 1926; 260: 215-33.

${ }^{28}$ Willis RA. Pathology of tumours, London: Butterworths 1967: 752.

${ }^{29}$ Stout AP, Lattes R. Tumours of soft tissues AFIP. Fascicle 1, 2nd Series, 1967: 94-8.

${ }^{30}$ Murray MR. Cultural characteristics of three granular cell myoblastomas. Cancer 1951; 4: 857-65.

${ }^{31}$ Pearse AGE. The histogenesis of granular cell myoblastoma. (?granular cell perineural fibroblastoma). J Pathol 1950; 62: 351-62.

${ }^{32}$ Garancis JC, Komorowski RA, Kuzma JF. Granular cell myoblastoma. Cancer $1970 ; 25: 542-50$.

${ }^{33}$ Aparicio SR, Lumsden CE. Light and electron-microscope studies on the granular cell myoblastoma of the tongue. J Pathol 1969; 97: 339-55.

${ }^{34}$ Fust JA, Custer RP. On the neurogenesis of the socalled granular cell myoblastoma. Am J Clin Pathol 1949; 19: 522-35.

${ }^{35}$ McCormack LJ, Hazard JB, Dickson JA. Malignant epithelioid neurilemoma (schwannoma). Cancer 1954; 7: 725-8.

${ }^{36}$ Ashley DJB. In: Evans' histological appearances of tumours. Livingstone: Churchill: 1978: 50-2.

${ }^{37}$ Whitmore JT, Whitley JP, LaVerde P, Cerda JJ. Granular cell myoblastoma of the common bile duct. Dig Dis Sci 1969; 14: 516-20.

${ }^{38}$ Zvargulis JE, Keating JP, Askin FB, Ternberg JL. Granular cell myoblastoma: a cause of biliary obstruction. Am J Dis Child 1978; 132: 68-70.
${ }^{39}$ Jain KM, Hastings OM, Rickert RR, Swaminathan AP Lazaro EJ. Granular cell tumour of the common bile duct. Am J Gastroenterol 1979; 71 : 401-7.

${ }^{40}$ Fialho F, Hilario J. Rabdomioma granuloso do cystico. $A M B$ 1952; 9: 616-8.

${ }^{41}$ Serpe SJ, Todd D, Barcuh H. Cholecystitis due to granular cell myoblastoma of the cystic duct. Dig Dis Sci 1960; 5: 824-26.

${ }^{42}$ Goldman LI, Lemole G, Ellis R, Rosemond G. Granular cell myoblastoma of the cystic dust. JAMA, 1967; 200: 1185-6.

${ }^{43}$ Mackay G, Elliott GB, MacDougall JA. Granular cell myoblastoma of the cystic duct: report of a case with electron microscopic observations. Can J Surg 1968; 11 : 44-51.

${ }^{44}$ Christensen $\mathrm{AH}$ and Ishak KG. Benign tumours and pseudo-tumours of the gall bladder. Report of 180 cases. Arch Pathol Lab Med 1970; 90: 423-32.

${ }^{45}$ Abt AB, Geinberg E, Kaunitz S. Granular cell myoblastoma of the extrahepatic biliary tree. Mt Sinai $J$ $\operatorname{Med}(N Y) 1971 ; 38: 457-61$.

${ }^{46}$ Reul GJ, Rubio PA, Berkman NL. Granular cell myoblastoma of the cystic duct. A case associated with hydrops of the gall bladder. Am J Surg 1975; 129: 583-4.

${ }^{47}$ Ishii T, Iri H, Yamamoto S, Shinozawa Y, Sudoh M. Granular cell myoblastoma of the gall bladder. Am J Gastroenterol 1977; 68: 38-44.

${ }^{48}$ Farris KB, Faust BF. Granular cell tumours of biliary ducts. Arch Pathol Lab Med 1979; 103: 510-2.

${ }^{49}$ Kittredge RD, Baer JW. Percutaneous transhepatic cholangiography. AJR $1975 ; 125$ : 35-46. 